\title{
The effect of training on productivity: The transfer of on-the-job training from the perspective of economics
}

Citation for published version (APA):

de Grip, A., \& Sauermann, J. (2013). The effect of training on productivity: The transfer of on-the-job training from the perspective of economics. Educational Research Review, 8, 28-36.

https://doi.org/10.1016/j.edurev.2012.05.005

Document status and date:

Published: 01/01/2013

DOI:

10.1016/j.edurev.2012.05.005

Document Version:

Publisher's PDF, also known as Version of record

Document license:

Taverne

Please check the document version of this publication:

- A submitted manuscript is the version of the article upon submission and before peer-review. There can be important differences between the submitted version and the official published version of record.

People interested in the research are advised to contact the author for the final version of the publication, or visit the DOI to the publisher's website.

- The final author version and the galley proof are versions of the publication after peer review.

- The final published version features the final layout of the paper including the volume, issue and page numbers.

Link to publication

\footnotetext{
General rights rights.

- You may freely distribute the URL identifying the publication in the public portal. please follow below link for the End User Agreement:

www.umlib.nl/taverne-license

Take down policy

If you believe that this document breaches copyright please contact us at:

repository@maastrichtuniversity.nl

providing details and we will investigate your claim.
}

Copyright and moral rights for the publications made accessible in the public portal are retained by the authors and/or other copyright owners and it is a condition of accessing publications that users recognise and abide by the legal requirements associated with these

- Users may download and print one copy of any publication from the public portal for the purpose of private study or research.

- You may not further distribute the material or use it for any profit-making activity or commercial gain

If the publication is distributed under the terms of Article $25 \mathrm{fa}$ of the Dutch Copyright Act, indicated by the "Taverne" license above, 
Review

\title{
The effect of training on productivity: The transfer of on-the-job training from the perspective of economics
}

\author{
Andries De Grip*, Jan Sauermann \\ ROA, Maastricht University and IZA, P.O. Box 616, NL-6200 MD Maastricht, The Netherlands
}

\section{A R T I C L E I N F O}

\section{Article history:}

Available online 1 June 2012

\section{Keywords:}

Returns to training

Skills

Informal learning

Transfer of skills

Employee performance

Human capital

\begin{abstract}
A B S T R A C T
Although the transfer of on-the-job training to the workplace belongs to the realm of educational research, it is also highly related to labour economics. In the economic literature the transfer of training is based on the theoretical framework of human capital theory and has been extensively analysed empirically in econometric studies that take account of unobserved heterogeneity of workers and the selectivity in training participation. The aim of this paper is to give an overview of the underlying theoretical paradigm in economics, and the challenges faced in empirical research. The economic literature finds that participation in training is beneficial for both the participating workers and their employers, although there is also evidence that selectivity of workers matters. Despite this progress in the economic literature, the underlying processes through which training leads to a higher productivity remain unclear. We argue that this 'black box' offers opportunities for multi-disciplinary research projects on the transfer of training that relate the perspectives of educational and economic research.
\end{abstract}

(c) 2012 Elsevier Ltd. All rights reserved.

\section{Contents}

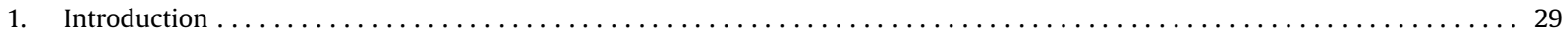

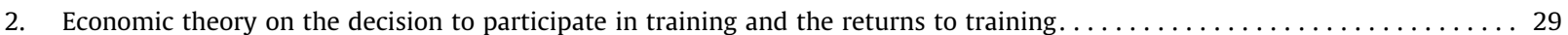

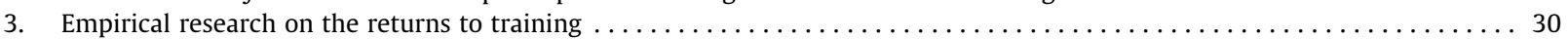

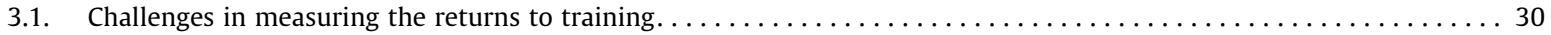

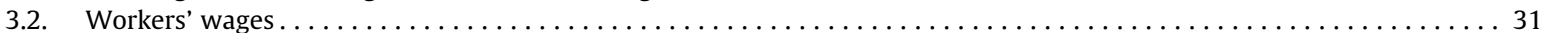

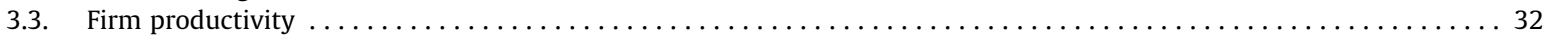

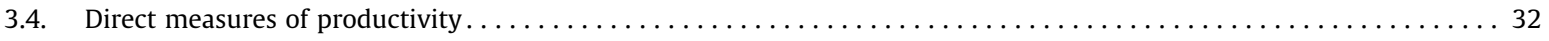

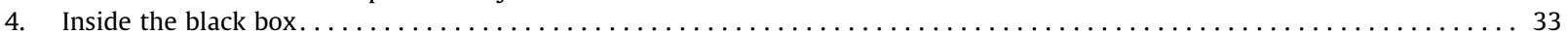

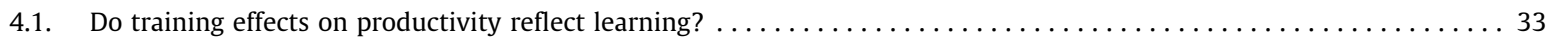

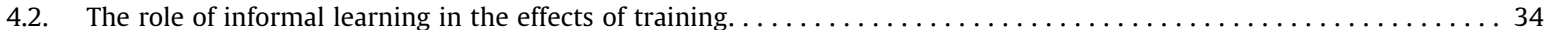

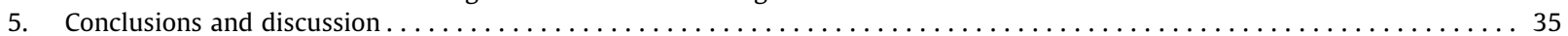

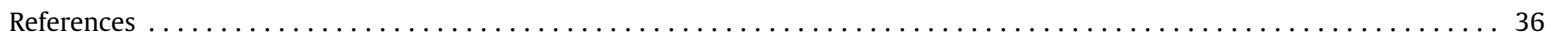

\footnotetext{
* Corresponding author. Tel.: +31 43 3883647; fax: +31 433884914 . E-mail address: a.degrip@maastrichtuniversity.nl (A. De Grip). URL: http://www.roa.unimaas.nl/cv/degrip/Degrip.htm (A. De Grip).
} 


\section{Introduction}

Research on the transfer of on-the-job training to the workplace has been subject to educational research, but is also highly related to labour economics. In the economic literature, the transfer of training is based on the theoretical framework of human capital theory and has been extensively analysed empirically in econometric studies that take account of unobserved heterogeneity of workers and selectivity in training participation. By focusing on the returns to training in terms of the productivity increase after the training, the economic literature is actually highly complementary to the research focus of the educational literature on the transfer of training to the workplace. In the context of the classification of Kirkpatrick (1994), the studies in the economic literature particularly refer to level 4, i.e. to what extent training matters for firm results. The economic literature shows that the returns to training on this level are better measured by individual productivity measures than by overall firm level results which may also be affected by other factors (see Wang, Dou, \& Li, 2002).

This paper aims at answering two questions

- How does economic literature deal with the transfer of training to the workplace?

- What is the scope for multi-disciplinary research projects on the transfer of training that relate the perspectives of educational research and economics?

For this purpose, we review the economic literature with the aim of providing an overview of the state-of-the-art in the economic literature on the returns to training instead of a review of the extensive literature on the estimation of the returns to training. In this overview, we will show the challenges related to the estimation of returns to training as well as the potential contribution of the economic literature to the studies on the 'transfer of training' in the educational literature. By focusing on the returns to training as measured by a worker's higher productivity after the training, the economic literature leaves a black box on the underlying processes through which the training improves a worker's productivity in the workplace. This black box actually refers to the research field of educational research. The purpose of this paper is therefore not to review transfer studies in the educational literature, but rather to outline and describe challenges and findings on the effects of training in the economic literature and thereby signalling the opportunities for interdisciplinary research.

There are three important aspects in which the economic literature on the returns to training has made substantial contributions. First, these studies use various measures of the effects of training, ranging from wages as a proxy for individual productivity to establishment level measures of productivity (i.e. the value added to be contributed to workers' performance in the job). Second, crucial to the analysis of the returns to training is how selection into training is controlled for. Third, a number of studies have attempted to look into the 'black box' of the ways in which training affects actual performance.

We focus on studies on the effects of workplace training, usually labelled as "on-the-job training". Because an integral part of this type of analysis involves measurement issues, we discuss challenges in the estimation of the "returns to training". Most studies on the returns to training conceptualise training by using survey information on workers' participation in training. While this allows estimating average effects of training (i.e. across different types of training and across different types of workers' tasks), this does not allow using detailed information on contents or types of training. For this reason, a few studies have analysed particular training programmes in econometric case studies that allow to go more into detail of how training affects productivity. At the same time, these studies are also more linked to studies in the educational literature as they evaluate particular training programmes and aim at looking into the 'black box' of the transfer of training to the workplace.

This article is structured as follows. In the next section of this article, we shortly present the theoretical 'human capital' model that is used as a theoretical framework for almost exclusively all empirical studies on the returns to training. In Section 3, we provide an overview across the main empirical contributions in economic literature. Section 4 discusses studies from the economic literature on the black box of how training affects performance. Section 5 summarises and concludes.

\section{Economic theory on the decision to participate in training and the returns to training}

The human-capital theory offers the theoretical framework in which labour economists started to study the impact of education and training on workers' performance in the labour market. Human capital theory was launched by a supplement volume of the Journal of Political Economy on 'Investments in Human Beings' in 1962 (e.g. Becker, 1962). The original human capital theory framework is a straightforward economic model of investments (and therefore expected costs) on the one hand, and expected returns on the other hand. Depending on the type of training, the investment consists of direct training costs (e.g. costs for learning material, coaches) and indirect training costs which arise from opportunity costs, i.e. the costs that arise because the training participant could have worked instead of following the training course. Though these costs and benefits do usually comprise monetary components (wages, increased performance, etc.), they could also consist of 'non-economic' components such as increases in motivation. Building on this general cost-benefit analysis that characterises the economic discipline, human capital theory states that a worker will only be trained when the discounted benefits after the training are expected to exceed the training costs. Though the original work implicitly assumes that participation leads to an increase in skills (human capital) and thus makes the worker more productive, positive returns to training could also be explained by other factors, such as higher motivation or stronger loyalty that workers may show after their employer has 
'invested' in them. In the latter case, training participation is considered to be a consumptive spending instead of an investment in human capital. This discussion shows that the economic literature is not primarily interested in measuring the increase in skills per se, but mainly in how far these skills increase various outcomes that are beneficial for the firm.

In the original work, an important conceptual distinction between different types of training is made. Becker (1962) and more recent advancements (Stevens, 1994) differentiate between general, transferable, and firm-specific training. General training is defined as training that affects general human capital and thus enhances a worker's productivity in all kinds of jobs. Examples for general training are for instance languages courses, or courses to improve general computer skills. While general knowledge and skills thus can be transferred to jobs in any other type firm, transferable knowledge and skills can only be transferred to jobs in similar firms, for example competing firms in the same sector of industry, or to similar jobs in the same craft or profession. This type often refers to vocational or professional skills (e.g. bricklaying, diagnoses of illnesses). Firm-specific training, however, can only be transferred to the workplace in the current firm. This training refers for instance to the acquisition of knowledge about machines or procedures that are only used in the firm where a worker is employed, or knowledge about specific characteristics of the products and clients of the firm.

This distinction has important implications for the investment behaviour of firms: while firms have an incentive to invest in firm-specific human capital, they have lower incentives to invest in general human capital and thus to cover the costs of the training as workers could use the training to bargain a higher wage or move to other firms at a higher wage rate (Acemoglu \& Pischke, 1999). Firms may prevent this problem by paying lower wages during the period in which the worker is trained, such as in the case of apprentices.

\section{Empirical research on the returns to training}

\subsection{Challenges in measuring the returns to training}

One of the main implications of human capital theory is that training investments are only undertaken if the expected rate of return is positive (Becker, 1962). Mainly due to the availability of data and appropriate methods, a large number of studies analysed the returns to training in the last two decades (see e.g. Bassanini, Booth, Brunello, De Paola, \& Leuven, 2007 for a comprehensive overview). Common to most of these studies is that they estimate an average effect for a group of workers, e.g. taken from a representative sample or taken from one firm. This average effect does not preclude that there is heterogeneity in the estimated effect which may be related to individual characteristics.

While the estimation of the returns to training seems to be straightforward, there are two main challenges to it (Dearden, Reed, \& Van Reenen, 2006). The first, selection bias, occurs if the treatment (participation in training) and the outcome (e.g. performance) are both affected by unobservable characteristics that are not known to the researcher. The best, yet impossible way to measure this effect is to observe one and the same individual at the same time in a 'treated' state (e.g. performance after participation in training) as well as an 'untreated' state (performance without participation in training) (Rosenbaum \& Rubin, 1983). Because this 'counterfactual' situation where the performance can be measured in both treated and untreated states is by definition not observable, the researcher has to compare groups of individuals that participated in training with groups of individuals that did not. As for other 'treatments' in the labour market, however, it is very likely that the firm's decision to send employees to training courses as well as individual's decisions to undergo training is not random, but depends on observable and unobservable individual characteristics. While researchers usually have information on a large set of control variables, there is by definition no information on unobservable characteristics. The selection bias arises if these observable and unobservable characteristics do not only affect training decisions but also the outcome, e.g. performance or wages. In the case of the estimation of returns to training, selection bias usually leads to an overestimation of the effects. I.e. studies that do not appropriately control for this selection may find positive estimates while the true effect is lower or even zero. A related problem to this type of selection bias is reverse causality. Reversed causation can occur when those who are promoted to a job at a higher level in the firm hierarchy participate in a training course that prepares them for their new job. The estimated treatment effect in the outcome variable can then not be attributed to training, but rather to career progression.

Second, it is important to have appropriate outcomes to measure the returns to training. When the researcher is interested in measuring the effectiveness or the transfer of training, the most appropriate measure is a measure that captures a worker's productivity, since it allows to measure the value added of what is transferred from training to the actual task of the worker. In reality, however, it is difficult to find measures of productivity that are measurable and comparable across workers or firms. For this reason, a substantial literature has developed that estimated the effects of participation in on-thejob training on workers' wages, mostly using representative surveys of the workforce. Wages, however, are not necessarily a good measure of the transfer to training since it only measures the share of the returns that eventually go to the worker and thus underestimate the 'true' transfer of training. For this reason, several other studies used representative establishment surveys and use indicators for productivity, e.g. sales or value-added, to estimate the returns. A third strand uses direct measures of productivity. This is by far the most precise way of measuring the transfer of training to the task, but comes at the costs of being less representative since direct measures of productivity are not available across jobs and sectors. This shows that studies in economics do not use measurements of skills to estimate the effectiveness of training, but are rather 
interested in the economic returns that justify the training costs, such as higher wages, higher productivity or a lower labour turnover.

\subsection{Workers' wages}

A large strand of studies in the economic literature has analysed the effects of training participation on workers' wages. The theoretical idea behind the effects on wages is that if firms pay according to the workers' marginal productivity, an increase in pay after the training reflects an increase in the underlying productivity. At the same time, increases in wages after training participation actually only reflect the share of the actual performance increase that is dedicated to the worker (Dearden et al., 2006).

Several studies find evidence for considerable returns to employees' participation in training. In a study on 14 European countries, Brunello (2004) finds that recently attended training increases a worker's income by about $12 \%$. Blanchflower and Lynch (1994) find a similar result for young persons in the US who participated in employer provided training. Other studies, however, claim that these high returns to training overestimate the actual returns to training because the wage increase of those who participated in training cannot be contributed to the training as such (Bassanini et al., 2007; Haelermans \& Borghans, 2011). The estimated effects of training are likely to be overestimated in the presence of selection bias.

In studies using (representative) survey data, scholars have introduced fixed effects estimation in which one is able to control for time-invariant effects, such as innate ability. If the unobservable characteristic of the worker is assumed not to change over time, these can be controlled for by introducing dummy variables for individuals. In his study on the US National Longitudinal Survey of Youth for years 1979-1991, Parent (1999) compares the results of simple ordinary least squares (OLS) estimates of the returns to employer-provided training with fixed-effects estimates. Whereas his OLS estimate of the returns to training is $16 \%$, the fixed effect estimate of the returns to training is only $12 \%$. This suggests that not controlling for selection bias does overestimate the effects of training.

Bassanini et al. (2007) estimate OLS and fixed effects regressions on workers' wage returns to training in 12 different European countries. Their analyses refer to full-time workers aged 25-59 whom are employed in the private sector. For their analyses they used the European Community Household Panel (ECHP) for the years 1995-97-99-01. Table 1 shows their findings for the various EU countries. OLS estimates of the training returns measured in hourly earnings range from $3.7 \%$ in the Netherlands to $21.6 \%$ in Greece. In general, the returns to training are highest in countries where training participation is rather low. In the fixed effect estimates the returns to training are considerably lower and insignificant in several countries. However, for Portugal (10.5\%) and Greece (6\%) the returns are still quite high, even when using fixed effects to control for unobservable worker characteristics.

At the same time, introducing fixed-effects estimate do only sufficiently control for selection bias if the assumption of time-invariance of the unobservable factors holds. For time-variant unobservable factors, even regressions with fixed effects will overestimate the returns to training. A number of other studies therefore attempt to identify the effect of training participation on a workers' productivity by using more advanced techniques to control for selection bias, e.g. by instrumental variable (IV) estimates (Angrist, Imbens, \& Rubin, 1996). The IV approach requires variables ('instruments') that are assumed to affect the decision to participate in training, but not the outcome variable (wages). The results of studies using IV methods, however, crucially depend on the credibility of the instrument, i.e. whether it is actually exogenous to the outcome variable. In general, these studies find much lower returns to training than OLS estimates (see Bassanini et al., 2007, for an overview).

Blundell, Dearden, Meghir, and Sianesi (1999) compare OLS without controlling for selection bias, fixed effect estimates, and IV estimates using the same data set on employer provided training. For male workers, OLS estimates show a wage

Table 1

Private returns to training.

\begin{tabular}{|c|c|c|}
\hline & OLS & Fixed effects \\
\hline Denmark & $.042^{* * * *}$ & $.020^{* * * *}$ \\
\hline Netherlands & $.037^{* *}$ & -.030 \\
\hline Belgium & $.055^{* * *}$ & $.026^{*}$ \\
\hline France & $.072^{* * * *}$ & .000 \\
\hline United Kingdom & $.079^{* * * *}$ & $.019^{*}$ \\
\hline Ireland & $.081^{* * * *}$ & .005 \\
\hline Italy & $.097^{* * *}$ & $.038^{* * *}$ \\
\hline Greece & $.216^{* * * *}$ & $.060^{*}$ \\
\hline Spain & $.072^{* * *}$ & .017 \\
\hline Portugal & $.180^{* * * *}$ & $.105^{* * * *}$ \\
\hline Austria & $.103^{* * * *}$ & .004 \\
\hline Finland & $.055^{* * *}$ & $.038^{* *}$ \\
\hline
\end{tabular}

Note: each regression include age, age squared, country, year, education, gender, marital status and industry dummies.

Source: Bassanini et al. (2007). Estimates are based on waves 1995, 1997, 1999, 2001 of the European Community Household Panel (ECHP).

**** $p<0.01$.

*** $p<0.05$.

$p<0.1$. 
return of $8.3 \%$, whereas the fixed effect estimate and IV estimate show lower returns of $5 \%$ and $6.5 \%$, respectively. Goux and Maurin (2000), however, find in their IV estimate that the returns to training in France appear to be close to zero.

The counterfactual model is most closely reached by an experiment where individuals are randomly placed in training programmes while others do not participate in training. While this is rather impossible to achieve in representative survey studies, Leuven and Oosterbeek (2008) attempt to resemble an experimental situation: they use information on the reasons for non-participation to create an artificial control group which did not participate in training because of an incidental reason, as compared to individuals which are not participating in training for non-random (or endogenous) reasons. When comparing the wages of the workers who participated in training with the wages of those in this more specific control group, Leuven and Oosterbeek do not find significant returns to training.

An alternative way of experimentally analysing the returns to training is to distribute training vouchers and to use the information on the voucher assignment as an instrument to identify the effects of training. Schwerdt, Messer, Woessmann, and Wolter (2011) exploit this type of experiment and estimate the wage returns to training. They do not find any significant effect of training on workers' wages. Overall, the evidence from this strand of literature suggests that the estimation of the returns to training crucially hinges on the way researchers control for selection bias.

A second reason for very low effects of training on outcomes, such as wages, is that - as in most other studies - training courses included in this analysis are often very short. Compared to the returns to education, the returns to training are very high (Haelermans \& Borghans, 2011). By merely participating in a short training course workers experience a sustainable improvement of their wage, ranging from $2 \%$ in Denmark and the United Kingdom to 10\% in Portugal (see Table 1). Bassanini et al. (2007) compare these returns with the returns to an additional year of initial education. For the three countries mentioned, one additional year of full-time education yields 6.4\% in Denmark, 9.4\% in the United Kingdom and 9.7\% in Portugal. This comparison shows that the returns to a short training course of employees are almost as high as the returns of a full year of initial education. This finding suggests that the transfer of knowledge and skills learned in a rather short training course to the workplace is much more effective than the transfer of knowledge and skills learned during initial education.

\subsection{Firm productivity}

While there are many studies on the wage effects of training participation, there are relatively few studies on the effects of training measured by means of more direct measures of productivity. However, in the past two decades, a stream of research has been emerging that analyses the effects of training by means of more straightforward measures of productivity. These studies use large-scale surveys across firms, establishments or industries.

As it is impossible to find a more direct measure of productivity that is comparable across industries, studies that include more sectors of industry use the value added or sales of firms as a measure of firm productivity (Black \& Lynch, 2001; Dearden et al., 2006; Zwick, 2006; Konings \& Vanormelingen, 2010). Because this measure of productivity is only available at the firm or establishment level, it can only be used at the firm or sector level. This, however, comes at the cost that this measure is less precise than when both training participation and productivity could be measured at the individual level.

In their study on the relationship between training participation and productivity across different industries, Dearden et al. (2006) find that the effects of training on workers' wages are about half the size of the effects of training participation on industrial productivity. They show that when average training participation in British industries would increase from $10 \%$ to $15 \%$ of the workforce firm productivity would on average increase by $4 \%$, whereas workers' wages would increase $1.5 \%$. In their study on different firms in manufacturing and services in Belgium, Konings and Vanormelingen (2010) also show that the effects of training on firm productivity are about twice the size of the effects of training on workers' wages. When controlling for various sources of worker heterogeneity, the latter find that the productivity premium for a trained employee is on average $17 \%$. Though large-scale surveys can have the advantage of providing a representative sample for one or more sectors of industry, they inherently suffer from unobservable heterogeneity in the type as well as duration of training programs and firms' production processes.

\subsection{Direct measures of productivity}

Both wages and establishment level measures of productivity are used to proxy an unknown measure of productivity. An alternative is to use direct measures of performance which have the advantage to be gathered at many firms, but the disadvantage that these measures are rarely comparable across firms. For this reason, some studies use direct measures of productivity within one sector of industry (for example Holzer et al., 1993) or for workers of a single firm (Bartel, 1995; Krueger \& Rouse, 1998; Liu \& Batt, 2007; De Grip \& Sauermann, 2012). An advantage of this type of measure is that most of these measures are automatically generated without interference of the supervisor and thus not subject to possibly subjective evaluations.

Holzer, Block, Cheatham, and Knott (1993) for example study the effects of state-financed training grants in manufacturing on firm performance. They use the product scrap rate as a measure of output quality, and find that these training grants increase the number of training hours and lead to a substantial lasting reduction of the scrap rate. Bartel (1995) uses performance ratings as a measure of productivity. She shows that workers who participated in a job related training course are significantly more likely to receive increases in their performance ratings. The disadvantage of using performance evaluations of supervisors is that these ratings are potentially subjective. Liu and Batt (2007) study the effects of on-the-job 
training on job performance of telephone operators in a large telecommunications firm. They also analyse to what extent workers with different levels of capability benefit from the training and take account of the possible depreciation of the performance effects of the training in the course of time. Liu and Batt measure workers' productivity by the average time an operator spends on a customer call. Estimating a first-difference model to control for worker heterogeneity they find a significant positive relationship between investment in on-the job learning and workers' productivity. The benefits of the training were sustained over several months. Furthermore, Liu and Batt's study shows that the less proficient workers benefit more from the training than the more proficient workers.

As for any type of analysis of the effects of training on performance, appropriately controlling for selection bias is crucial for the validity of the results. The cleanest way to reach the counterfactual model and thus to estimate causal effects of participation in training on performance is to use experimental variation in the participation in training. Yet, this is also the most difficult approach to achieve given that experiments are more difficult to undertake in or across firms. The only study, so far, exploiting truly randomised participation in training is the study by De Grip and Sauermann (2012). In this study, call agents of a call centre were randomly assigned to participation in a five-day training program. Though all agents in this experiment had to be trained, a treatment and control groups approach could be applied because not the participation per se, but the order in which agents participated was randomised. After half of the agents were trained, there was no training for the agents for several weeks. This period, during which a randomly chosen half of the agents was not (yet) been treated, serves as a post-treatment period during which the performance of treated and untreated agents can be compared.

The authors find that participation in the training programme leads to a performance increase in average handling time of almost $10 \%$. Furthermore, they show evidence that working with treated peers increases the performance of untreated workers: an increase in the share of treated peers by $10 \%$ points leads to an increase of performance of untreated workers by $.5 \%$. When considering these within-team externalities, the firm appears to recover the training costs in the eighth week after the training. These findings confirm the relevance of the interactional perspective to training transfer as discussed by Weisweiler, Nikitopoulos, and Frey (2012) and related to the notion of the role of a worker's social network in the transfer of training (see Van den Bossche \& Segers, 2012).

Though case studies cannot provide results that are representative by definition, they have at least three important advantages. First, compared to survey studies, firms generate substantial amount of data on the performance of either teams or individuals that can be used to evaluate the effects of training. This is not possible at the representative level where the researcher is dependent on alternative proxies, such as wages or establishment productivity measures. Second, the researcher has more 'insider' information on the selection of individuals into training, but also more in general on the firm's human resource policy. Third, this enables potential exogenous variation that can be imposed by the researcher which is barely impossible on the representative level.

\section{Inside the black box}

\subsection{Do training effects on productivity reflect learning?}

Despite the substantial research on the effects of training on productivity in the economic literature, there has been relatively little research in the actual reasons of the treatment effect. We can see this as a 'black box' in the economic literature on the transfers of training to the workplace. An important question is whether training affects performance via skills, or whether it is other factors, such as workers higher motivation which increases their performance. Furthermore, it is important to assess the role of (formal) training programmes for other types of learning, such as informal learning.

The literature reviewed so far assumes that positive effects of training on different measures of productivity can be explained by an increase in skills. However, there are no studies that attempt to directly measure skills itself. Having measures of productive skills would also then allow to open the black box on the transfer of training to the workplace in economic literature. One study that uses a straightforward method to analyse skills, is Green, Ashton, and Felstead (2001) who measure these skills by asking workers about the importance of particular activities that require these skills in their job. They thereby, however, assume that respondents' job duties are an unbiased measure of their skills. The questions they use have been drawn from the Job Analysis literature and cover questions in order to measure of computing, problem solving, communication, social as well as team-working skills. Problem solving skills, for example, are captured by four questions on the importance of (1) spotting problems or faults, (2) working out the cause of them, (3) devising solutions to them, and (4) analyzing complex problems. Green et al. (2001) then analyse the determinants of these skills and find that off-the-job-training is a determinant of all types of key skills included in their analysis except team working, whereas on-the-job training is only effective for learning of problem-solving and team-working skills.

In the economic literature, however, the way in which training leads to higher productivity is usually a black box that does not reveal whether it is the higher knowledge or skill level or a higher motivation or firm loyalty which drives the higher productivity after training. Actually, various studies, published in economics as well as in HRM journals, analyse the effects of training on workers' job satisfaction (e.g. Georgellis \& Lange, 2007) and commitment to the firm (e.g. Koster, De Grip, \& Fouarge, 2011). The link between training and other outcomes, such as job satisfaction and commitment, indicates that not only skills are affected by training but also other outcomes. These outcomes, in turn, may then affect performance, while the skills itself may not been affected. 
These studies show that training participation can affect workers' work motivation and efforts in three ways (see Koster et al., 2011). First, firms that are supportive in developing their employees can induce their workers to feel more committed to the organization. Second, employees perceive the companies that provides training courses for their workforce as organizations which show their concern for the maintenance or growth of the competences of their workforce. The latter is supported by Shields and Ward (2001) who found that workers' dissatisfaction with training opportunities has a stronger impact on job satisfaction than their dissatisfaction with workload and pay. Third, the possibility to develop new skills enhances employees' employability both within and outside the firm (see Hoon Lee \& Bruvold, 2003). Although the increased work efforts can be interpreted as manifestations of the transfers of training to the workplace they merely refer to a motivational effect of training as the source of a higher performance after a training, instead of a transfer of knowledge or skills. This finding is in line with the findings on motivational influences on training effectiveness in organisational psychology and educational science (see Noe, 1986; Gegenfurtner, Vauras, \& Veermans, 2012).

Sicherman and Galor (1990) show that part of the returns to investments in human capital is in the form of a higher probability to be promoted to a higher job level. From this perspective, Bartel (1995) distinguishes between core training which focuses on skills needed to keep up with current job requirements, and employee development or career training. Dekker, De Grip, and Heijke (2002) use this distinction to analyse the effects of training on upward mobility. They find that participation in career training increases workers upward mobility significantly suggesting that the career training prepared them for their promotion. In their study on low-skilled workers, Sanders and De Grip (2004) find that training participation only contribute to the firm-internal mobility of workers. These studies suggest that training courses are not necessarily focused on improving workers' skills in their current job but might also intend to improve skills which can only be applied in a higherlevel job.

\subsection{The role of informal learning in the effects of training}

Borghans, Golsteyn, De Grip, and Nelen (2009) focus their analysis on the relationship between training participation and informal learning on-the-job. In the Lifelong Learning Survey 2007, respondents indicate that one additional hour of formal training increases the time that workers learn during their job by $1.2 \mathrm{~h}$. Furthermore, this survey asked the respondents who participated in a training course whether the training stimulated them to learn more during their work. About $34 \%$ of those who participated in a training course answered that the course improved their on-the-job learning after the course. These findings suggest that training courses are a catalyst for informal learning at work. Training enables workers to learn more at work. From the perspective of the question whether there is a transfer of the knowledge and skills learned during a training to the workplace, this is a very important notion. The complementarities between training and informal learning in the workplace indicate that there is not merely a transfer of the knowledge and skills learned during the training but on top of this also additional learning at work. Heckman (2007) qualifies these kind of complementarities the "dynamic complementarities" of human capability formation.

However, as most studies on the returns to training in the economic literature do not measure the additional time spent on workplace learning, all the benefits of the knowledge and skill acquisition of the workers will be attributed to workers' participation in formal training. By not including the time actually spent on informal workplace learning, these studies will actually overestimate the returns on formal training. So it is the complementarities between formal training and informal workplace learning which explains why participating in a course for only a few days can have such large effects on workers' earnings and firm productivity.

Borghans et al. provide detailed information on the working time Dutch workers spend on activities from which they learn on-the-job. On average, workers appear to spend $31 \%$ of their working time on such activities which is much more than the time they spend on their participation in formal training. Actually, only $6 \%$ of the time workers are involved in activities from which they learn refers to their participation in formal training courses; the remaining $94 \%$ refers to the time they spend on informal learning activities at work. Borghans et al. also find that the reason why someone participates in a training course affects the intensity of informal learning after the training. Dynamic complementarities between participation in a training course and learning at work particularly occur when workers participate in a training because they want to:

- compensate a perceived skill gap for their current job;

- improve the opportunities for another job;

or when:

- they have new tasks to do at work;

- new modes of working are introduced.

These results show that the (gross) returns to training will be particularly high when the skills demanded in the job require further training. Moreover, it suggests that for example task rotation or job rotation also create dynamic complementarities between training and learning on the job. 


\section{Conclusions and discussion}

In the economic literature, human capital theory offers the theoretical foundation for studies on the transfer of training to the workplace. The basic idea of this model is that positive effects of training are due to learning new skills that make workers more productive in their job which will be reflected in higher wages. In this literature, the transfer of the knowledge and skills learned in a training course is conceptualized as the training-related increase of workers' productivity. The theoretical idea behind this is that there are different types of skills which vary by their transferability to other firms or industries. While general training refers to learning knowledge or skills that can be transferred to jobs within the company as well as jobs in other firms, firm-specific training can only be transferred to the current workplace. Furthermore, transferable training refers to training vocational knowledge or skills that can be transferred to a restricted number of other firms in the same sector of industry.

Over the last decades, many empirical studies have been estimating the productivity increase related to training participation by using wages or establishment productivity as a measure of productivity. In the last two decades, however, there is an emerging literature that analyses the effects of training by means of more direct measures of workers' productivity. Most empirical studies find that participation in training is very beneficial for both the participating workers and the firms. At the same time, several studies have shown that returns to training are considerably lower when regression analyses attempt to identify a causal effect of training participation on workers' productivity by taking account of a possible selection bias.

We can conclude that the economic literature offers a useful framework for studies on the transfer of training to the workplace. By focusing on the returns in terms of value added or productivity related key performance indicators of firms, the economic literature is actually highly complementary to the research focus of the educational literature on the transfer of training to the workplace as the latter much more focuses on the specific knowledge and skills transferred to the workplace, i.e. the underlying processes through which participating in a training course improves a worker's productivity. Though the economic literature implicitly assumes that the improvements in workers' productivity are due to improvements of their skills, this does not necessarily be the case. Instead, other reasons (motivation, loyalty to the firm) might also explain the increase in performance after training participation.

This difference between economic research and educational research is actually reflected in Kirkpatrick's typology of the different levels of evaluating training programs. Whereas the educational literature focuses on Kirkpatrick's levels 2 (Learning, i.e. the resulting increase in knowledge or skills) and 3 (Behaviour, i.e. the extent of behaviour and capability improvement and application), studies in the field of human capital theory focus on level 4 (Results, i.e. the effects on the business or environment resulting from the trainee's performance). Moreover, the economic literature shows that the returns to training on Kirkpatrick's level 4 could better be measured by indicators of individual productivity than by overall firm level results that may have confounding factors (Wang et al., 2002).

Although the human capital framework allows for including both cognitive and non-cognitive skill effects of training, there are only few studies which attempt to analyse the ways in which training participation improves workers' productivity. Some studies suggest that workers' higher productivity after the training is not related to a transfer of knowledge or skills to the workplace but are particularly a result of an improvement of workers' loyalty to the firm and motivation to deliver more efforts in return. However, other studies also find positive effects of training participation of workers' skill levels and knowledge development. Moreover, the study of Borghans et al. (2009) shows that training participation also encourages learning on-the-job after the training. This suggests that there might not only be a transfer of the knowledge and skills learned during the training to the workplace but on top of this also additional learning at work as a benefit of the training. This points at the existence of dynamic complementarities between participation in a training course and learning at work.

However, the economic literature still leaves a large black box which could be filled by educational research assessed within an econometric framework on worker and firm performance which indicates the returns on training investments. Within this framework, these studies should focus on the various drivers of the transfer of training to the workplace, such as the acquired knowledge and skills (De Corte, 2003), the different modes of training, and different dimensions of workers' motivation to transfer and moderator effects (see Gegenfurtner, 2011) as well as job and work environment characteristics indicate the transfer climate at work (Weisweiler et al., 2012). These multi-disciplinary research projects on the transfer of training to the workplace building on educational science and economics will be very promising in enlightening the various dimensions of the transfer of training that lead to a higher productivity at the worker and firm level, and the possible dynamic complementarities between participation in a training course and learning at work. Definitely, these multi-disciplinary research projects will not only contribute to our understanding of the transfer of the knowledge and skills learned in training to the workplace. They will also increase insights in the factors that can increase the extent of this transfer as well as the drivers of dynamic complementarities between training participation and further informal learning at the job.

These multi-disciplinary research projects will improve the relevance of both economic and educational research for the business world. As we showed in this paper, the economic literature on the transfer of training to the workplace largely ignores the analysis of the underlying processes through which training affects workers' performance in the workplace. Though the actual improvement of skills is a likely way through which workers' performance is affected, other reasons, such as effects on motivation or loyalty might also partly explain the positive effects of training. It is particularly this 'black box' where there is scope for multi-disciplinary research that relates the economic and educational perspectives. Both disciplines could benefit from this multi-disciplinary approach. Whereas economic research could become richer by a better under- 
standing of the ways in which various kinds of training and training methodologies can improve workers' productivity, educational research on the transfer of training could become more relevant for the business world for which the economic costbenefit paradigm is the dominant perspective.

\section{References}

Acemoglu, D., \& Pischke, J.-S. (1999). The structure of wages and investment in general training. Journal of Political Economy, 107(3), 539-572.

Angrist, J. D., Imbens, G. W., \& Rubin, D. B. (1996). Identification and causal effects using instrumental variables. Journal of the American Statistical Association, $91,444-455$.

Bartel, A. P. (1995). Training. Wage growth, and job performance evidence from a company database, journal of labor economics, 13 , $401-425$.

Bassanini, A., Booth, A. L., Brunello, G., De Paola, M., \& Leuven, E. (2007). Workplace training in Europe. In G. Brunello, P. Garibaldi, \& E. Wasmer (Eds.), Education and Training in Europe. Oxford: Oxford University Press.

Becker, G. S. (1962). Investment in human capital: A theoretical analysis. Journal of Political Economy, 70, 9-49.

Black, S. E., \& Lynch, L. M. (2001). How to compete: The impact of workplace practices and information technology on productivity. Review of Economics and Statistics, 83, 434-445.

Blanchflower, D. G., \& Lynch, L. M. (1994). Training at work: A comparison of U.S. and British youths. In L. M. Lynch (Ed.), Training and the Private Sector: International Comparisons (pp. 233-260). Comparative Labor Market Series, Chicago and London: University of Chicago Press.

Blundell, R., Dearden, L., Meghir, C., \& Sianesi, B. (1999). Human capital investment: The returns from education and training to the individual, the firm and the economy. Fiscal Studies, 20, 1-23.

Borghans, L., Golsteyn, B., De Grip, A., Nelen A. (2009). De betekenis van het leren op het werk, ECBO, ‘s-Hertogenbosch/Amsterdam.

Brunello, G. (2004). Labour market institutions and the complementarity between education and training in Europe. In D. Checchi \& C. Lucifora (Eds.), Education, Training and Labour Market Outcomes in Europe (pp. 188-209). Palgrave Macmillan: Houtmills.

Dearden, L., Reed, H., \& Van Reenen, J. (2006). The impact of training on productivity and wages: Evidence from British Panel Data. Oxford Bulletin of Economics and Statistics, 68, 397-421.

De Corte, E. (2003). Transfer as the productive use of acquired knowledge, skills and motivations. Current Directions in Psychological Science, $12,142-146$.

De Grip, A., \& Sauermann, J. (2012). The effects of training on own and co-worker productivity: Evidence from a field experiment. The Economic Journal, 122, 376-399.

Dekker, R., De Grip, A., \& Heijke, H. (2002). The effects of training and overeducation on career mobility in a segmented labour market. International Journal of Manpower, 23, 106-125.

Gegenfurtner, A. (2011). Motivation and transfer in professional training: A meta-analysis of the moderating effects of knowledge type, instruction, and assessment conditions. Educational Research Review, 6(3), 153-168.

Gegenfurtner, A., Vauras, M., \& Veermans, K. (2012). Effects of time lag, computer support, and collaboration on performance self-efficacy and transfer of training: A longitudinal meta-analysis. Educational Research Review, 7(3).

Georgellis, Y., \& Lange, T. (2007). Participation in continuous on-the-job training and job satisfaction: Longitudinal evidence from the German labour market. International Journal of Human Resource Management, 18, 969-985.

Goux, D., \& Maurin, E. (2000). Returns to firm-provided training: evidence from French worker-firm matched data. Labour Economics, 7, 1-19.

Green, F., Ashton, D., \& Felstead, A. (2001). Estimating the determinants of supply of computing problem-solving, communication, social, and teamworking skills. Oxford Economic Papers, 53, 406-433.

Haelermans, C., Borghans, L. (2011). Wage effects of on-the-job training: A meta-analysis, ROA Research Memorandum $11 / 2011$.

Heckman, J. (2007). The economics, technology and neuroscience of human capability formation, IZA discussion papers 2875. Bonn: Institute for the Study of Labor.

Holzer, H. J., Block, R. N., Cheatham, M., \& Knott, J. H. (1993). Are training subsidies for firms effective? The Michigan experience. Industrial and Labor Relations Review, 46, 625-636.

Hoon Lee, C., \& Bruvold, N. T. (2003). Creating value for employees: Investment in employee development. International Journal of Human Resource Management, 14, 981-1000.

Kirkpatrick, D. L. (1994). Evaluating Training Programs, the Four Levels. San Francisco: Berrett-Koehler Publishers.

Konings, J., Vanormelingen, S. (2010). The impact of training on productivity and wages: Firm level evidence, IZA discussion paper 4731, Institute for the Study of Labor (IZA), Bonn.

Koster, F., De Grip, A., \& Fouarge, D. (2011). Does perceived support in employee development affect personnel turnover? International Journal of Human Resource Management, 22, 2403-2418.

Krueger, A., \& Rouse, C. (1998). The effect of workplace education on earnings, turnover, and job performance”. Journal of Labor Economics, $16,61-94$.

Leuven, E., \& Oosterbeek, H. (2008). An alternative approach to estimate the wage returns to private-sector training. Journal of Applied Econometrics, 23(4), 423-434.

Liu, X., \& Batt, R. (2007). The economic pay-offs to informal training: evidence from routine service work. Industrial and Labor Relations Review, 61(1), 75-89.

Noe, R. A. (1986). Trainee attributes and attitudes: Neglected influences on training effectiveness. Academy of Management Review, 11, 736-749.

Parent, D. (1999). Wages and mobility: The impact of employer-provided training. Journal of Labor Economics, 17, $298-317$.

Rosenbaum, P. R., \& Rubin, D. B. (1983). The central role of the propensity score in observational studies for causal effects. Biometrika, 70(1), 41-55.

Sanders, J., \& De Grip, A. (2004). Training and low-skilled Workers 'Employability. International Journal of Manpower, $25,73-89$.

Schwerdt, G., Messer, D., Woessmann, L., Wolter, S. (2011). Effects of adult education vouchers on the labor market: Evidence from a randomized field experiment, IZA discussion papers No. 5431, Institute for the Study of Labor (IZA), Bonn.

Shields, M. A., \& Ward, M. E. (2001). Improving nurse retention in the British National Health Service. The impact of job satisfaction on the intentions to quit. Journal of Health Economics, 20, 677-701.

Sicherman, N., \& Galor, O. (1990). A theory of career mobility. Journal of Political Economy, 98, 169-192.

Stevens, M. (1994). A theoretical model of on-the-job training with imperfect competition. Oxford Economic Papers, 46, $537-562$.

Van den Bossche, P., \& Segers, M. (2012). Transfer of training: Adding insight through social network analysis. Educational Research Review, 7(3).

Wang, G. G., Dou, Z., \& Li, N. (2002). A systems approach to measuring return on investments for HRD interventions. Human Resource Development Quarterly, $13,203-224$.

Weisweiler, S., Nikitopoulos, A., \& Frey, D. (2012). Gaining insight to transfer of training through the lense of social psychology. Educational Research Review, $7(3)$.

Zwick, T. (2006). The impact of training intensity on establishment productivity. Industrial Relations, 45(1), 26-46. 